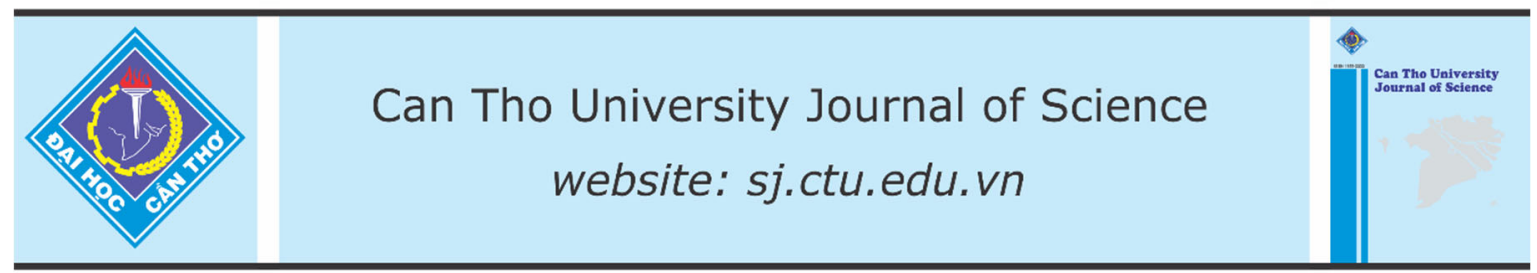

DOI: 10.22144/ctu.jen.2019.011

\title{
Evaluating the effects of single cell detritus from red seaweed (Gracillaria tenuistipitata) and gutweed (Enteromorpha sp.) on growth of Artemia franciscana
}

Ngo Thi Thu Thao

College of Aquaculture and Fisheries, Can Tho University, Vietnam

Correspondence: Ngo Thi Thu Thao (email: thuthao@ctu.edu.vn)

\section{Article info.}

Received 10 Jun 2018

Revised 06 Oct 2018

Accepted 29 Mar 2019

\section{Keywords}

Artemia, diet, Enteromorpha, Gracillaria tenuistipitata, single cell detritus

\begin{abstract}
The ability to produce single cell detritus (SCD) from different seaweed species, red seaweed, Gracillaria tenuistipitata and green seaweed, Enteromorpha sp. was determined, and the effects of selected SCD diet on survival rate, growth performance and reproductive characteristics of Artemia franciscana were assessed under laboratory conditions. Experiment 1 included 8 treatments with red and green seaweeds, combined with yeast fermentation at different densities $\left(0,10^{4}, 10^{5}, 10^{6}\right.$ cells $\left./ \mathrm{mL}\right)$. The results showed that the density of SCD reached highest at day 7 in the treatments added $10^{6}$ yeast cells $/ \mathrm{mL}\left(88.480 \pm 2.769 \times 10^{6}\right.$ and $100.752 \pm 2.687 \times 10^{6}$ cells $/ m L$ of red and green seaweeds, respectively). Although the density of $S C D$ was highest at $10^{6}$ yeast cell $/ \mathrm{mL}$, the yeast density and $\mathrm{NH}_{4}^{+}$concentration in green seaweed fermentation were high $(5-10 \mathrm{mg} / \mathrm{L})$. Thus, the treatment of red seaweed and $10^{5}$ yeast cell $/ \mathrm{mL}$ obtained the suitable ability to harvest at day 7 and preserve SCD for feeding Artemia. In experiment 2, Artemia were fed with 5 different diets, and each diet has three replications. Commercial feed No. 0 (for shrimp postlarvae) was the control, and 4 diets in which the shrimp feed was replaced by SCD with proportion of 100, 75, 50 and 25\%. Results showed that diet with 50\% shrimp feed and $50 \%$ SCD showed the high survival rate and good growth performance, as well as positive effects on the reproductive characteristics of Artemia franciscana.
\end{abstract}

Cited as: Thao, N.T.T., 2019. Evaluating the effects of single cell detritus from red seaweed (Gracillaria tenuistipitata) and gutweed (Enteromorpha sp.) on growth of Artemia franciscana. Can Tho University Journal of Science. 11(1): 78-86.

\section{INTRODUCTION}

Microalgae species are an essential feed source and have been chosen to produce aquaculture seed in the hatchery for a long time. However, microalgae culture procedure takes time and is unstable, in some cases, the production depends mainly on weather conditions. The problem arisen is the necessary of the alternative food source which has low cost, simple feeding procedure, and ensures the requirements of nutrients, digestibility. Single cell detritus (SCD) is a good idea for solving this problem (Uchida, 1996; Camacho et al., 2004; Ngo Thi Thu Thao and Nguyen Huynh Anh Huy, 2017). The term "SCD" just appeared in the scientific field in late 1990s, and the first study of SCD was done by Uchida (1996). SCD is not a living cell, this term describes a food that is separated from the body fragments of seaweed into single cell, single-cell differentiated from algae - the unicellular microalgae living. Depending on the species of seaweed, harvesting methods and preservation of the SCD will bring different characteristics of nutritional value. Studies on SCD have been 
conducted on Artemia (Uchida et al., 1997), the clam Ruditapes decussatus (Camacho et al., 2004), oyster Crassostrea belcheri (Tanyaros and Chuseingjaw, 2016), showing its potential use in aquaculture practices.

Recently, the results from Ngo Thi Thu Thao and Nguyen Huynh Anh Huy (2017) and Ngo Thi Thu Thao et al. (2018) showed that SCD harvested from red seaweed Gracillaria tenuistipitata and fermented with yeast Saccharomyces cerevisiae (SCD-Y) obtained the density of $301 \times 10^{4}$ particles $/ \mathrm{mL}$. The authors also found that the diet with $100 \%$ SCD-Y or a combination of $50 \%$ SCD and $50 \%$ shrimp feed presented the relatively high survival rate, good growth performance of Artemia, as well as a positive influence on the maturity of $A$. franciscana. However, the source of $G$. tenuistipipitata was transported from the central region of Vietnam, and sometimes it will be shortage for SCD production. Gutweed, Enteromorpha sp. commonly occurred in the brackish waters in Mekong Delta of Vietnam, this green seaweed has been found in several provinces such as Soc Trang, Bac Lieu, Ca Mau and can be potential source to prepare SCD. This study was carried out to determine the ability to produce SCD from different seaweeds, G. tenuistipitata and Enteromorpha sp., and evaluate the effects of selected SCD diet on survival rate, growth performance and reproductive characteristics of Artemia franciscana under laboratory conditions. Results from this study will be useful in practices that the feed sources for filter feeders such as zooplankton, crustacean or bivalve mollusks can be actively handled in the laboratories or hatcheries.

\section{MATERIALS AND METHODS}

There were 2 experiments in this study. The first experiment was conducted to evaluate the yield and proximate composition of SCD from different seaweed sources. In second experiment, the best SCD product in term of density and proximate composition was used as a feed for Artemia franciscana to assess the growth performance, survival rate and reproduction of this species.

\subsection{Experiment 1: Evaluating the yield and proximate compositions of SCD from red seaweed, G. tenuistipitata and gutweed, Enteromorpha sp.}

Dried red seaweed was bought from market in Nha Trang, Khanh Hoa province, and gutweed was collected from canals in Bac Lieu province. At the laboratory, fresh gutweeds were rinsed, removed debris and bio-fouling organisms, and then materials were dried indoor for 24-48 hours depending on weather conditions. Both seaweed sources then were ground separately with blender to obtain powder before applying techniques to prepare SCD. The reverse osmosis technique of Tanyaros et al. (2014) was modified to produce SCD, which includes three steps. Step 1: 100 grams dry seaweed was homogenized by using food blender and sieved through a $200 \mu \mathrm{m}$ mesh screen. Step 2: 10 grams product from step 1 and $250 \mathrm{~mL}$ freshwater was placed into $500 \mathrm{~mL}$ Erlenmeyer flask. The samples were shaken at $100 \mathrm{rpm}$ within 2 hours. Step 3: SCD was harvested after supplying yeast (for fermentation) and $70 \mathrm{mg} / \mathrm{L}$ glucose (nutritional solution for yeast) within 48 hours. Then SCD was sieved through a $50 \mu \mathrm{m}$ mesh screen.

The experiment included 8 treatments and four replications for each treatment as follows: 1) red seaweed without yeast adding (RS0); 2) red seaweed $+10^{6}$ yeast cells $\left./ \mathrm{mL}\left(\mathrm{RS} 10^{6}\right) ; 3\right)$ red seaweed $+10^{5}$ yeast cells $\left./ \mathrm{mL}\left(\mathrm{RS} 10^{5}\right) ; 4\right)$ red seaweed $+10^{4}$ yeast cells $/ \mathrm{mL}\left(\mathrm{RS} 10^{4}\right)$; 5) green seaweed without yeast adding (GS0); 6) green seaweed $+10^{6}$ yeast cells $\left./ \mathrm{mL}\left(\mathrm{GS} 10^{6}\right) ; 7\right)$ green seaweed $+10^{5}$ yeast cells $\left./ \mathrm{mL}\left(\mathrm{GS} 10^{5}\right) ; 8\right)$ green seaweed $+10^{4}$ yeast cells $/ \mathrm{mL}\left(\mathrm{GS} 10^{4}\right)$.

\subsubsection{Data collection}

$\mathrm{pH}$ value, $\mathrm{NO}_{2}{ }^{-}$and $\mathrm{NH}_{4} / \mathrm{NH}_{3}$ concentrations were checked at day $1,4,7$, and 10 by SERA test kits (Germany).

\subsubsection{Evaluating the yield and proximate compositions of SCD}

Samples to determine the density of SCD and yeast were collected at day 1, 4, 7 and 10. Improved Newbauer was used for cell counting and the formula as follows:

$$
N\left(\frac{\operatorname{cell}(s)}{m l}\right)=\frac{n}{64} \times 10^{4}
$$

Where: $\mathrm{n}$ is total of SCD/yeast cells counted in 64 small boxes in counting chamber.

Solutions of red or green seaweeds were centrifuged, dried at $60^{\circ} \mathrm{C}$ in oven for 24 hours and sent to laboratory to analyze proximate compositions such as protein, lipid, carbohydrate, fiber, calcium, phosphorus and ash (AOAC, 2000).

\subsection{Experiment 2: Evaluating the effects of SCD from red seaweed on growth performance, survival rate and reproduction of Artemia franciscana}

\subsubsection{Experiment design and management}

The best result from experiment $1\left(10^{5}\right.$ yeast cells $/ \mathrm{mL}$ in the fermentation of red seaweed to 
prepare SCD) was selected for feeding Artemia in experiment 2. Some criteria such as the highest SCD density and lowest density of yeast. In addition, some environmental parameters such as $\mathrm{pH}$, concentration of $\mathrm{NO}_{2}$ and $\mathrm{NH}_{4} / \mathrm{NH}_{3}$ were also considered to select the best SCD product.

In experiment 2, Artemia individuals were fed by microalgae Chaetoceros sp. during the first two days. From day 3 onwards, different diets and four replications for each were fed as follows: Treatment 1 (control, CF): 100\% commercial feed; Treatment 2 (S100): 100\% SCD; Treatment 3 (S75): 75\% SCD $+25 \%$ artificial feed; Treatment 4 (S50): $50 \%$ SCD $+50 \%$ artificial feed; Treatment 5 (S25): $25 \%$ SCD $+75 \%$ artificial feed.

SCD preparation: Red seaweed was fermented with $10^{5}$ yeast cells $/ \mathrm{mL}$ and $70 \mathrm{mg} / \mathrm{L}$ glucose. SCD was harvested at day 7 after centrifuging and drying (at $60^{\circ} \mathrm{C}$ during 24 hours), then SCD product was stored at $4^{\circ} \mathrm{C}$ to feed Artemia.

Incubating Artemia cyst: Artemia cysts were incubated with one litter seawater 30\%. Aeration and lighting were used continuously during incubation. After 20-24 hours, aeration tube was used to collect newly hatched larvae which were then counted to arrange into the glass bottles to culture.

Artemia culture: Twenty glass bottles contented of 2 litters of seawater 30\% . Newly hatching Artemia was released at density of 100 inds./L. Aeration and lighting were supplied continuously during culture period. Artemia was fed three times per day at $7 \mathrm{am}$, $2 \mathrm{pm}$ and $9 \mathrm{pm}$. On first day, all Artemia was fed with Chaetoceros algae at the density of 50,000 cells/mL. Next day, it was 100,000 cells/mL. From the third day, Artemia was fed with five feeding treatments above. Commercial feed for tiger shrimp postlarvae (40-42\% protein) was dipped in seawater $30 \%$ for 15 minutes before filtering through a 50 $\mu \mathrm{m}$ mesh. The amount of feed for Artemia was based on the calculation of Nguyen Van Hoa et al. (2007). Water in each Artemia cultured bottle was renewed $30 \%$ every 3 days.

\subsubsection{Data collection}

\section{a. Environmental parameters}

$\mathrm{pH}$ value, $\mathrm{NO}_{2}{ }^{-}$and $\mathrm{NH}_{4} / \mathrm{NH}_{3}$ concentrations were checked in Artemia bottles at the day 1, 5, 9, 13, 17 and 21 by test kits (SERA of Germany). Temperature was recorded daily at 7 am and $2 \mathrm{pm}$. Salinity was maintained around $30 \%$ during culture period.

\section{b. Growth performance, survival rate and reproduction of Artemia}

Samples of 10 Artemia from each cultured bottle were collected and fixed in formalin solution to measure total length. Total length of Artemia was measured at day $1,5,9,13,17$ and 21 from head to the end of tail through a binocular fitted with micrometer eyepiece.

Formula:

$$
L(m m)=\frac{A}{10} \times \frac{1}{\gamma}
$$

Where: L: length of Artemia (mm), A: the length under binocular, $\gamma$ : magnification

The number of alive Artemia was counted at day 7, 14 and 21 to calculate survival rate, the following formula:

$$
S R(\%)=\frac{N_{2} \times 100}{N_{1}}
$$

Where: $\mathrm{N}_{1}$ : initial number of Artemia, $\mathrm{N}_{2}$ : the number of Artemia at collecting time

When Artemia started matching, each couple was collected, recorded and transferred into a new bottle. A number of 15 males and 15 females were collected to determine the length at first matching. Every three days from the first matching, 15 gravity females from each treatment were collected to determine fecundity and reproductive mode.

Matching rate:

$$
M R(\%)=\frac{C \times 2 \times 100}{M}
$$

Where: C: number of couples, $\mathrm{M}$ : initial number of Artemia

Fecundity (embryo/female) of female Artemia was determined by sampling of 15 females in each treatment, and then brood sack was operated to count the number of embryos inside.

\subsection{Statistical analysis}

Data analysis was done by one-way ANOVA to compare the differences between the mean values of the treatments by Duncan test in SPSS 22 at significance level of 0.05 .

\section{RESULTS}

\subsection{Experiment 1: Evaluating the yield and proximate compositions of SCD from red}


seaweed, G. tenuistipitata and gutweed, Enteromorpha sp.

\subsubsection{Variation of environmental parameters}

The $\mathrm{pH}$ fluctuated from $4.85 \pm 0.08$ to $7.95 \pm 0.08$, depending on the fermented days and seaweed powder sources. The treatments with red seaweed showed lower $\mathrm{pH}$ value which decreased during the experiment period. For the treatments with red seaweed, $\mathrm{RC} 0$ showed the highest $\mathrm{pH}$ value and was significantly different from the others in day 1,7 and 10 .
The fluctuations of $\mathrm{pH}$ among treatments of red seaweed with different yeast densities were tightly ( $4.85 \pm 0.08$ to $5.25 \pm 0.08$ ) and did not show clearly the significant difference. Whereas, $\mathrm{pH}$ values were high in green seaweed fermented solutions and increased from $6.45 \pm 0.08$ to $7.95 \pm 0.08$ during the experiment. The difference of $\mathrm{pH}$ between two kinds of seaweed might cause the action of decomposing microorganisms.

Table 1: Mean of pH values in SCD solutions of different seaweeds

\begin{tabular}{lrrrr}
\hline \multirow{2}{*}{ Treatments } & \multicolumn{4}{c}{ Day of experiment } \\
\cline { 2 - 5 } & \multicolumn{1}{c}{$\mathbf{1}$} & $\mathbf{4}$ & $\mathbf{7}$ & $\mathbf{1 0}$ \\
\hline RS10 & $5.10 \pm 0.16^{\mathrm{a}}$ & $4.85 \pm 0.08^{\mathrm{a}}$ & $4.90 \pm 0.07^{\mathrm{ab}}$ & $4.90 \pm 0.11^{\mathrm{a}}$ \\
RS10 & $5.00 \pm 0.04^{\mathrm{a}}$ & $4.85 \pm 0.08^{\mathrm{a}}$ & $4.85 \pm 0.08^{\mathrm{a}}$ & $4.85 \pm 0.05^{\mathrm{a}}$ \\
RS10 & $5.00 \pm 0.07^{\mathrm{a}}$ & $4.85 \pm 0.05^{\mathrm{a}}$ & $5.00 \pm 0.04^{\mathrm{b}}$ & $5.00 \pm 0.43^{\mathrm{a}}$ \\
RS0 & $5.25 \pm 0.08^{\mathrm{b}}$ & $4.90 \pm 0.07^{\mathrm{a}}$ & $5.15 \pm 0.08^{\mathrm{c}}$ & $5.10 \pm 0.43^{\mathrm{b}}$ \\
$\mathrm{GS} 10^{6}$ & $6.60 \pm 0.07^{\mathrm{B}}$ & $7.30 \pm 0.07^{\mathrm{A}}$ & $7.60 \pm 0.15^{\mathrm{AB}}$ & $7.90 \pm 0.07^{\mathrm{B}}$ \\
GS10 & $6.65 \pm 0.05^{\mathrm{B}}$ & $7.25 \pm 0.12^{\mathrm{A}}$ & $7.80 \pm 0.43^{\mathrm{B}}$ & $7.95 \pm 0.08^{\mathrm{B}}$ \\
GS10 & $6.60 \pm 0.04^{\mathrm{B}}$ & $7.25 \pm 0.11^{\mathrm{A}}$ & $7.80 \pm 0.43^{\mathrm{B}}$ & $7.90 \pm 0.04^{\mathrm{B}}$ \\
GS0 & $6.45 \pm 0.08^{\mathrm{A}}$ & $7.30 \pm 0.13^{\mathrm{A}}$ & $7.45 \pm 0.15^{\mathrm{A}}$ & $7.70 \pm 0.11^{\mathrm{A}}$ \\
\hline
\end{tabular}

Data with different normal or capital letters in the same column showed the significant difference $(p<0.05)$

In treatments of red seaweed, $\mathrm{NH}_{4}{ }^{+}$concentration was low and fluctuated from $0.25 \pm 0.25$ to $1.0 \pm 0.82$ $\mathrm{mg} / \mathrm{L}$. Whereas, the treatment with green seaweed showed very high concentrations of $\mathrm{NH}_{4}^{+}$(5.0 to $10 \mathrm{mg} / \mathrm{L})$. The results may cause the strong decomposing action of microorganisms. Different seaweed also showed the different fiber structure, green seaweed was soft and easy to separate, whereas red seaweed was hard and difficult to separate. The results showed that after fermentation, red seaweed contented higher fiber than green seaweed $(9.6 \%$ and $3.86 \%$ for red and green seaweeds, respectively).

Table 2: Mean of $\mathrm{NH}_{4}^{+}$concentration (mg/L) in SCD solutions from different seaweeds

\begin{tabular}{|c|c|c|c|c|}
\hline \multirow{2}{*}{ Treatments } & \multicolumn{4}{|c|}{ Day of experiment } \\
\hline & 1 & 4 & 7 & 10 \\
\hline $\mathrm{RS} 10^{6}$ & $0.50 \pm 0.00^{\mathrm{a}}$ & $1.00 \pm 0.22^{\mathrm{a}}$ & $1.00 \pm 0.22^{\mathrm{a}}$ & $1.00 \pm 0.22^{\mathrm{a}}$ \\
\hline $\mathrm{RS} 10^{5}$ & $0.50 \pm 0.22^{\mathrm{a}}$ & $1.00 \pm 0.22^{\mathrm{a}}$ & $1.00 \pm 0.22^{\mathrm{a}}$ & $1.00 \pm 0.22^{\mathrm{a}}$ \\
\hline $\mathrm{RS} 10^{4}$ & $0.50 \pm 0.22^{\mathrm{a}}$ & $1.00 \pm 0.00^{\mathrm{a}}$ & $1.00 \pm 0.36^{\mathrm{a}}$ & $1.00 \pm 0.22^{\mathrm{a}}$ \\
\hline RS0 & $0.50 \pm 0.25^{\mathrm{a}}$ & $1.00 \pm 0.35^{\mathrm{a}}$ & $1.00 \pm 0.35^{\mathrm{a}}$ & $1.00 \pm 0.82^{\mathrm{a}}$ \\
\hline $\mathrm{GS} 10^{6}$ & $5.00 \pm 2.17^{\mathrm{A}}$ & $10.00 \pm 0.00^{\mathrm{A}}$ & $10.00 \pm 0.00$ & $10.00 \pm 0.00$ \\
\hline $\mathrm{GS} 10^{5}$ & $7.50 \pm 2.50^{\mathrm{A}}$ & $10.00 \pm 0.00^{\mathrm{A}}$ & $10.00 \pm 0.00$ & $10.00 \pm 0.00$ \\
\hline $\mathrm{GS} 10^{4}$ & $7.50 \pm 2.50^{\mathrm{A}}$ & $10.00 \pm 0.00^{\mathrm{A}}$ & $10.00 \pm 0.00$ & $10.00 \pm 0.00$ \\
\hline GS0 & $5.00 \pm 1.73^{\mathrm{A}}$ & $10.00 \pm 1.17^{\mathrm{A}}$ & $10.00 \pm 0.00$ & $10.00 \pm 0.00$ \\
\hline
\end{tabular}

Data with different normal or capital letters in the same column showed the significant difference $(p<0.05)$

In this study, $\mathrm{NO}_{2}$ concentration was really low and not significantly different among the treatments $(p>0.05)$, despite of red or green seaweed sources.
The reason might be from the short time of fermentation, so there was no presence of bacteria to convert $\mathrm{NH}_{4}^{+} / \mathrm{NH}_{3}$ to $\mathrm{NO}_{2}$ 
Table 3: Mean of concentration $\mathrm{NO}_{2}(\mathrm{mg} / \mathrm{L})$ in $\mathrm{SCD}$ solutions from different seaweeds

\begin{tabular}{lcccr}
\hline \multirow{2}{*}{ Treatments } & \multicolumn{4}{c}{ Day of experiment } \\
\cline { 2 - 5 } & $\mathbf{1}$ & $\mathbf{4}$ & $\mathbf{7}$ & $\mathbf{1 0}$ \\
\hline RS10 & 0.00 & $0.00 \pm 0.00^{\mathrm{a}}$ & $0.00 \pm 0.00^{\mathrm{a}}$ & $0.00 \pm 0.00^{\mathrm{a}}$ \\
RS10 & 0.00 & $0.00 \pm 0.00^{\mathrm{a}}$ & $0.00 \pm 0.00^{\mathrm{a}}$ & $0.00 \pm 0.00^{\mathrm{a}}$ \\
RS10 & 0.00 & $0.00 \pm 0.00^{\mathrm{a}}$ & $0.00 \pm 0.00^{\mathrm{a}}$ & $0.25 \pm 0.25^{\mathrm{a}}$ \\
RS0 & 0.00 & $0.00 \pm 0.00^{\mathrm{a}}$ & $0.00 \pm 0.00^{\mathrm{a}}$ & $0.50 \pm 0.22^{\mathrm{a}}$ \\
GS10 & 0.00 & $0.00 \pm 0.00^{\mathrm{A}}$ & $0.00 \pm 0.00^{\mathrm{A}}$ & $0.00 \pm 0.00^{\mathrm{A}}$ \\
GS10 & 0.00 & $0.00 \pm 0.00^{\mathrm{A}}$ & $0.00 \pm 0.00^{\mathrm{A}}$ & $0.00 \pm 0.00^{\mathrm{A}}$ \\
GS10 & 0.00 & $0.00 \pm 0.00^{\mathrm{A}}$ & $0.00 \pm 0.00^{\mathrm{A}}$ & $0.25 \pm 0.25^{\mathrm{A}}$ \\
GS0 & 0.00 & $0.00 \pm 0.00^{\mathrm{A}}$ & $0.00 \pm 0.00^{\mathrm{A}}$ & $0.50 \pm 0.22^{\mathrm{A}}$ \\
\hline
\end{tabular}

Data with different normal or capital letters in the same column showed the significant difference $(p<0.05)$

\subsubsection{Variation of SCD densities}

After harvesting, SCD was microscopic particles, in various size with light green color and smaller than yeast cells. In both red and green seaweed fermented solutions, the highest SCD density was presented in the treatment adding $10^{6}$ yeast cells $/ \mathrm{mL}$ at day 7 $\left(88.48 \pm 2.77 \times 10^{6}\right.$ cells $/ \mathrm{mL}$ and $100.75 \pm 2.69 \times 10^{6}$ cells $/ \mathrm{mL})$, then followed by treatment fermented with $10^{5}$ yeast cells $/ \mathrm{mL}\left(69.92 \pm 1.28 \times 10^{6}\right.$ cells $/ \mathrm{mL}$ and $92.25 \pm 1.70 \times 10^{6}$ cells $\left./ \mathrm{mL}\right)$. SCD density decreased obviously at day 10 in all treatments. While with control treatment, the SCD density reached the highest density at day $4\left(18.29 \pm 0.58 \times 10^{6}\right.$ cells $/ \mathrm{mL}$ and $54.4 \pm 1.67 \times 10^{6}$ cells $/ \mathrm{mL}$ ), and then decreased (Table 4).

Table 4: SCD densities in different treatments (million cells $/ \mathrm{mL})$

\begin{tabular}{lrrrr}
\hline \multirow{2}{*}{ Treatments } & \multicolumn{4}{c}{ Day of experiment } \\
\cline { 2 - 5 } & \multicolumn{1}{c}{$\mathbf{1}$} & $\mathbf{4}$ & $\mathbf{7}$ & $\mathbf{1 0}$ \\
\hline RS10 & $28.34 \pm 0.77^{\mathrm{d}}$ & $66.2 \pm 2.52^{\mathrm{d}}$ & $88.48 \pm 2.77^{\mathrm{d}}$ & $56.58 \pm 0.98^{\mathrm{d}}$ \\
RS10 & $24.25 \pm 1.13^{\mathrm{c}}$ & $51.46 \pm 2.60^{\mathrm{c}}$ & $69.92 \pm 1.28^{\mathrm{c}}$ & $39.26 \pm 1.11^{\mathrm{c}}$ \\
RS10 & $17.35 \pm 0.83^{\mathrm{b}}$ & $33.59 \pm 1.90^{\mathrm{b}}$ & $43.45 \pm 1.46^{\mathrm{b}}$ & $25.12 \pm 1.07^{\mathrm{b}}$ \\
RS0 & $14.22 \pm 1.34^{\mathrm{a}}$ & $18.29 \pm 0.58^{\mathrm{a}}$ & $16.04 \pm 0.42^{\mathrm{a}}$ & $8.77 \pm 0.45^{\mathrm{a}}$ \\
GS10 & $69.98 \pm 1.53^{\mathrm{D}}$ & $94.40 \pm 2.23^{\mathrm{D}}$ & $100.75 \pm 2.69^{\mathrm{D}}$ & $85.05 \pm 0.71^{\mathrm{D}}$ \\
GS10 & $59.99 \pm 1.77^{\mathrm{C}}$ & $70.61 \pm 0.98^{\mathrm{C}}$ & $92.25 \pm 1.70^{\mathrm{C}}$ & $67.02 \pm 1.11^{\mathrm{C}}$ \\
GS10 & $50.93 \pm 2.31^{\mathrm{B}}$ & $60.94 \pm 1.13^{\mathrm{B}}$ & $73.73 \pm 1.67^{\mathrm{B}}$ & $45.90 \pm 1.66^{\mathrm{B}}$ \\
GS0 & $42.45 \pm 1.57^{\mathrm{A}}$ & $54.40 \pm 1.67^{\mathrm{A}}$ & $40.01 \pm 1.23^{\mathrm{A}}$ & $23.50 \pm 0.87^{\mathrm{A}}$ \\
\hline
\end{tabular}

Data with different normal or capital letters in the same column showed the significant difference $(p<0.05)$

Table 5 showed that the density of yeast increased with time during the experiment. The treatment with highest yeast density adding resulted in highest number at day $10\left(365.85 \pm 5.21 \times 10^{4}\right.$ cells $/ \mathrm{mL}$, $390.2 \pm 5.17 \times 10^{4}$ cells $/ \mathrm{mL}$ for red and green seaweed, respectively).

Table 5: Yeast densities in different treatments (thousands cells $/ \mathrm{mL}$ )

\begin{tabular}{lrrrr}
\hline \multirow{2}{*}{ Treatments } & \multicolumn{4}{c}{ Day of experiment } \\
\cline { 2 - 5 } & \multicolumn{1}{c}{$\mathbf{4}$} & $\mathbf{4}$ & $\mathbf{1 0}$ \\
\hline RS10 & $98.5 \pm 7.45^{\mathrm{d}}$ & $126.95 \pm 8.92^{\mathrm{d}}$ & $262.35 \pm 5.24^{\mathrm{d}}$ & $390.2 \pm 5.17^{\mathrm{d}}$ \\
RS10 & $10.15 \pm 0.62^{\mathrm{c}}$ & $11.92 \pm 0.92^{\mathrm{c}}$ & $71.13 \pm 1.95^{\mathrm{c}}$ & $101.36 \pm 4.89^{\mathrm{c}}$ \\
RS10 & $1.03 \pm 0.08^{\mathrm{b}}$ & $1.16 \pm 0.08^{\mathrm{b}}$ & $15.05 \pm 0.26^{\mathrm{b}}$ & $29.35 \pm 0.84^{\mathrm{b}}$ \\
RS0 & $0^{\mathrm{a}}$ & $0^{\mathrm{a}}$ & $0^{\mathrm{a}}$ & $0^{\mathrm{a}}$ \\
GS10 & $98.50 \pm 3.64^{\mathrm{D}}$ & $119.75 \pm 8.30^{\mathrm{D}}$ & $270.45 \pm 1.76^{\mathrm{D}}$ & $365.85 \pm 5.21^{\mathrm{D}}$ \\
GS10 & $10.0 \pm 0.69^{\mathrm{C}}$ & $12.35 \pm 0.41^{\mathrm{C}}$ & $69.97 \pm 2.23^{\mathrm{C}}$ & $125.70 \pm 5.26^{\mathrm{C}}$ \\
GS10 & $0.99 \pm 0.03^{\mathrm{B}}$ & $1.28 \pm 0.05^{\mathrm{B}}$ & $16.90 \pm 0.58^{\mathrm{B}}$ & $37.23 \pm 2.26^{\mathrm{B}}$ \\
GS0 & $0^{\mathrm{A}}$ & $0^{\mathrm{A}}$ & $0^{\mathrm{A}}$ & $0^{\mathrm{A}}$ \\
\hline
\end{tabular}

Data with different normal or capital letters in the same column showed the significant difference $(p<0.05)$

Proximate composition of SCD

Proximate compositions of SCD from red and green seaweeds were illustrated in Table 6. Both red and green seaweeds after fermentation with yeast showed the increase in percentages of protein, fiber, ash and calcium while carbohydrate, phosphorus and lipid were decreased. SCD of red seaweed contented higher percentage of protein, lipid, fiber and carbohydrate than in SCD of green seaweed. 
Based on the data of SCD solutions, SCD and yeast density, the best result for harvesting SCD was red seaweed fermented with $10^{5}$ yeast cells/mL at day 7 .
Therefore, this fermented formula was applied to produce SCD for feeding Artemia in the $2^{\text {nd }}$ experiment.

Table 6: Proximate compositions of SCD from different seaweeds (\% dry weight)

\begin{tabular}{lrrrr}
\hline \multirow{2}{*}{ Proximate composition } & \multicolumn{3}{c}{ Red seaweed } & Green seaweed \\
\cline { 2 - 5 } & Raw material & SCD & Raw material & SCD \\
\hline Protein & 17.65 & 22.43 & 16.01 & 21.16 \\
Lipid & 0.88 & 0.59 & 2.00 & 0.14 \\
Fiber & 4.54 & 9.60 & 3.47 & 3.86 \\
Carbohydrate & 52.84 & 38.08 & 45.32 & 35.44 \\
Ash & 4.09 & 9.30 & 33.20 & 39.40 \\
Phosphorus & 1.24 & 0.63 & - & 0.42 \\
Calcium & 0.93 & 1.09 & - & 0.89 \\
\hline
\end{tabular}

3.2 Experiment 2: Evaluating the effects of selected SCD diet on reproduction, growth and survival rate of Artemia

\subsubsection{Environmental parameters in Artemia culture medium}

During the experiment, temperature fluctuated from $27.17 \pm 0.05^{\circ} \mathrm{C}$ to $31.3 \pm 0.05^{\circ} \mathrm{C}$. In general, this temperature was suitable for Artemia. $\mathrm{pH}$ fluctuated from $8.67 \pm 0.04$ to $8.75 \pm 0.08$. In treatments feeding with SCD from red seaweed $G$. tenuistipitata, concentrations of $\mathrm{NH}_{4}{ }^{+}$and $\mathrm{NO}_{2}$ were lower than those in commercial feed treatments. Treatment AF or S25 showed the concentration of $\mathrm{NH}_{4}^{+}$and $\mathrm{NO}_{2}$ much higher and significant difference from the others $(\mathrm{p}<0.05)$.

Table 7: Environmental parameters in different treatments during Artemia culture period

\begin{tabular}{lrrrrr}
\hline Treatments & $\begin{array}{r}\text { Temperature } \\
\left(\mathbf{A M},{ }^{\mathbf{0}} \mathbf{C}\right)\end{array}$ & $\begin{array}{r}\text { Temperature } \\
\left(\mathbf{P M},{ }^{\mathbf{0}} \mathbf{C}\right)\end{array}$ & $\mathbf{p H}$ & $\begin{array}{r}\mathbf{N H}_{4}{ }^{+/ \mathbf{N H}_{3}} \\
(\mathbf{m g} / \mathbf{L})\end{array}$ & $\mathbf{N O}_{2}(\mathbf{m g} / \mathbf{L})$ \\
\hline CF & $27.24 \pm 0.03$ & $31.30 \pm 0.05$ & $8.67 \pm 0.04$ & $1.38 \pm 0.05^{\mathrm{d}}$ & $0.82 \pm 0.03^{\mathrm{c}}$ \\
S100 & $27.24 \pm 0.03$ & $31.20 \pm 0.05$ & $8.67 \pm 0.07$ & $0.82 \pm 0.06^{\mathrm{a}}$ & $0.55 \pm 0.03^{\mathrm{a}}$ \\
S75 & $27.17 \pm 0.05$ & $31.30 \pm 0.02$ & $8.75 \pm 0.08$ & $0.97 \pm 0.02^{\mathrm{b}}$ & $0.53 \pm 0.00^{\mathrm{a}}$ \\
S50 & $27.24 \pm 0.02$ & $31.20 \pm 0.02$ & $8.75 \pm 0.08$ & $0.98 \pm 0.03^{\mathrm{b}}$ & $0.55 \pm 0.03^{\mathrm{a}}$ \\
S25 & $27.19 \pm 0.01$ & $31.20 \pm 0.02$ & $8.75 \pm 0.04$ & $1.13 \pm 0.04^{\mathrm{c}}$ & $0.72 \pm 0.02^{\mathrm{b}}$ \\
\hline
\end{tabular}

Data with different letters in the same column showed the significant difference $(p<0.05)$

3.2.2 Survival rate, growth and reproduction of Artemia

In day 7, the highest survival rate of Artemia presented in CF (98\%), followed by S25 and S50 $(96 \%)$, and there were significant differences from
$\mathrm{S} 100$ and $\mathrm{S} 75(\mathrm{p}<0.05)$. However, at day 14 , highest survival rate of Artemia ( $93 \pm 1.7 \%$ ) was recorded in the treatment S50. The lowest survival rate presented in treatment $\mathrm{CF}(50 \%)$, whereas these values were still high in S50 (71\%) and S25 (61\%) at day 21.

Table 8: Survival rate of Artemia in different feeding treatments (\%)

\begin{tabular}{lrrr}
\hline Treatments & Day 7 & Day 14 & Day 21 \\
\hline CF & $97.67 \pm 2.52^{\mathrm{c}}$ & $78.00 \pm 4.58^{\mathrm{ab}}$ & $53.00 \pm 3.51^{\mathrm{ab}}$ \\
S100 & $89.00 \pm 1.00^{\mathrm{a}}$ & $72.17 \pm 7.78^{\mathrm{a}}$ & $51.33 \pm 4.16^{\mathrm{a}}$ \\
S75 & $92.33 \pm 2.08^{\mathrm{b}}$ & $78.00 \pm 5.29^{\mathrm{ab}}$ & $58.00 \pm 2.00^{\mathrm{bc}}$ \\
S50 & $96.67 \pm 1.15^{\mathrm{c}}$ & $92.33 \pm 2.08^{\mathrm{c}}$ & $68.33 \pm 3.06^{\mathrm{d}}$ \\
S25 & $96.00 \pm 1.00^{\mathrm{c}}$ & $86.67 \pm 4.16^{\mathrm{bc}}$ & $63.67 \pm 5.51^{\mathrm{c}}$ \\
\hline
\end{tabular}

Data with different letters in the same column showed the significant difference $(p<0.05)$

The length of Artemia became significantly different among treatments $(\mathrm{p}<0.05)$ at day 5 . Treatment $\mathrm{CF}$ showed the highest value $(4.11 \pm 0.09 \mathrm{~mm})$, whereas the lowest in treatment S100
$(3.30 \pm 0.23 \mathrm{~mm})$. However, from day 13 , the treatment of S50 showed the best result in length of $\mathrm{Ar}$ temia with the significant difference from the others $(\mathrm{p}<0.05)$ while the lowest Artemia length presented in treatment S100. 
Table 9: Length of Artemia $(\mathrm{mm})$ in different treatments during the experiment period

\begin{tabular}{crrrrr}
\hline \multirow{2}{*}{ Culture day } & \multicolumn{5}{c}{ Feeding treatments } \\
\cline { 2 - 6 } & $\mathbf{C F}$ & $\mathbf{S 1 0 0}$ & $\mathbf{S 7 5}$ & $\mathbf{S 5 0}$ & S25 \\
\hline 1 & $0.45 \pm 0.00^{\mathrm{a}}$ & $0.46 \pm 0.00^{\mathrm{a}}$ & $0.45 \pm 0.00^{\mathrm{a}}$ & $0.45 \pm 0.00^{\mathrm{a}}$ & $0.45 \pm 0.00^{\mathrm{a}}$ \\
5 & $4.11 \pm 0.09^{\mathrm{d}}$ & $3.30 \pm 0.23^{\mathrm{a}}$ & $3.40 \pm 0.08^{\mathrm{ab}}$ & $3.65 \pm 0.02^{\mathrm{bc}}$ & $3.84 \pm 0.08^{\mathrm{c}}$ \\
9 & $6.05 \pm 0.10^{\mathrm{c}}$ & $4.34 \pm 0.12^{\mathrm{a}}$ & $4.50 \pm 0.10^{\mathrm{ab}}$ & $4.80 \pm 0.17^{\mathrm{b}}$ & $5.72 \pm 0.24^{\mathrm{c}}$ \\
13 & $7.13 \pm 0.10^{\mathrm{ab}}$ & $6.93 \pm 0.06^{\mathrm{a}}$ & $7.10 \pm 0.13^{\mathrm{ab}}$ & $7.45 \pm 0.06^{\mathrm{c}}$ & $7.23 \pm 0.04^{\mathrm{b}}$ \\
17 & $7.58 \pm 0.07^{\mathrm{a}}$ & $7.60 \pm 0.06^{\mathrm{ab}}$ & $7.76 \pm 0.04^{\mathrm{b}}$ & $7.90 \pm 0.06^{\mathrm{c}}$ & $7.76 \pm 0.09^{\mathrm{b}}$ \\
21 & $7.68 \pm 0.05^{\mathrm{a}}$ & $7.70 \pm 0.06^{\mathrm{ab}}$ & $7.85 \pm 0.04^{\mathrm{b}}$ & $8.40 \pm 0.10^{\mathrm{c}}$ & $7.80 \pm 0.02^{\mathrm{ab}}$ \\
\hline
\end{tabular}

Data with different letters in the same row showed the significant difference $(p<0.05)$

After 21 days of culture, the highest matching rate was in CF treatment $(20.5 \pm 1.25 \%)$, followed by S25 $(18.5 \pm 4.77 \%)$, and the lowest one was in S100 (8.5 \pm 3.66$)$. Length at the first match of Artemia was highest in CF treatment $(8.50 \pm 0.16 \mathrm{~mm})$ and significantly different from others $(\mathrm{p}<0.05)$. Furthermore, the S50 treatment also obtained the high result in growth $(7.13 \pm 0.06 \mathrm{~mm}$ at day 11$)$ and reproduction of Artemia.

Table 10: Some reproductive parameters of Artemia franciscana

\begin{tabular}{llrrrrr}
\hline \multirow{2}{*}{ Parameters } & \multicolumn{7}{c}{ Feeding treatments } \\
\cline { 2 - 7 } & $\mathbf{C F}$ & $\mathbf{S 1 0 0}$ & $\mathbf{S 7 5}$ & $\mathbf{S 5 0}$ & S25 & CF \\
\hline Day of first match & 10 & 13 & 11 & 11 & 10 \\
Matching rate (\%) & $20.50 \pm 1.25^{\mathrm{b}}$ & $8.50 \pm 3.66^{\mathrm{a}}$ & $11.50 \pm 1.84^{\mathrm{a}}$ & $13.50 \pm 1.31^{\mathrm{ab}}$ & $18.50 \pm 4.77^{\mathrm{b}}$ \\
Embryos/female & $73.00 \pm 0.57^{\mathrm{b}}$ & $40.00 \pm 1.37^{\mathrm{a}}$ & $75.00 \pm 3.14^{\mathrm{b}}$ & $71.00 \pm 1.78^{\mathrm{b}}$ & $66.00 \pm 0.42^{\mathrm{b}}$ \\
Female length Matching day & $8.50 \pm 0.16^{\mathrm{d}}$ & $6.75 \pm 0.16^{\mathrm{a}}$ & $6.75 \pm 0.06^{\mathrm{a}}$ & $7.13 \pm 0.06^{\mathrm{b}}$ & $7.63 \pm 0.06^{\mathrm{c}}$ \\
$(\mathrm{mm})$ & Day 21 & $8.70 \pm 0.05^{\mathrm{c}}$ & $7.69 \pm 0.14^{\mathrm{a}}$ & $7.60 \pm 0.12^{\mathrm{a}}$ & $8.20 \pm 0.05^{\mathrm{b}}$ & $8.30 \pm 0.12^{\mathrm{b}}$ \\
Male length & Matching day & $7.25 \pm 0.16^{\mathrm{b}}$ & $5.75 \pm 0.12^{\mathrm{a}}$ & $5.88 \pm 0.06^{\mathrm{a}}$ & $6.00 \pm 0.16^{\mathrm{a}}$ & $7.75 \pm 0.06^{\mathrm{c}}$ \\
$(\mathrm{mm})$ & Day 21 & $7.55 \pm 0.11^{\mathrm{d}}$ & $6.70 \pm 0.14^{\mathrm{a}}$ & $6.80 \pm 0.09^{\mathrm{b}}$ & $7.20 \pm 0.09^{\mathrm{c}}$ & $7.76 \pm 0.04^{\mathrm{e}}$ \\
\hline
\end{tabular}

Data with different letters in the same row showed the significant difference $(p<0.05)$

The average fecundity of female Artemia fluctuated from $40 \pm 1.37$ to $75 \pm 3.14$ offspring/brood. The treatments of CF, S25 or S50 showed the highest result and significant difference from the others $(\mathrm{p}<0.05)$. These results showed that $100 \%$ CF could be the best diet for growth, maturation and reproduction of Artemia. However, the replacement by SCD from $25-50 \%$ in the diet also showed the similar results, and it meant that those diets probably fulfilled the nutritional requirements for Artemia, especially for maturation and reproduction stage.

\section{DISCUSSIONS}

The maximum SCD density in this study was higher than the number of $33.7 \pm 7.0 \times 10^{4}$ cells $/ \mathrm{mL}$ in the study of Tanyaros and Chuseingjaw (2016). It was because of the difference in ratio of seaweed - water volume and method of harvesting SCD $(4 \% \mathrm{w} / \mathrm{v}$ and sieved by $50 \mu \mathrm{m}$ mesh screen compared with $0.2 \%$ $\mathrm{w} / \mathrm{v}$ and sieved by $20 \mu \mathrm{m}$ mesh screen of Tanyaros and Chuseingjaw, 2014). However, this result was lower than the result of Camacho et al. (2004) who obtained the number of $3.0 \times 10^{8}$ cells $/ \mathrm{mL}$ ( $\mathrm{SCD}$ size from 2-20 $\mu \mathrm{m}$ ). The difference caused by the authors used the ratio of $10 \% \mathrm{w} / \mathrm{v}$ while this study's ratio was $4 \% \mathrm{w} / \mathrm{v}$. In addition, the authors harvested
SCD from 3 steps: hydration; treatment with acid, enzyme (endoglucanases and cellulase); and decomposition by microorganism (Pseudoalteromonas espejiana and Vibrio sp.). This study just added yeast (S. cerevisiae) for fermentation after shaking. Density of SCD in the research of Uchia and Murata (2002) was $5.8 \times 10^{7}$ from $5 \%$ seaweed Undaria, $3.5 \% \mathrm{NaCl}, 0.5 \%$ enzyme cellulose, $10^{9}$ cells $/ \mathrm{mL}$ Lactobacillus brevis, $5.3 \times 10^{5}$ cells $/ \mathrm{mL}$ Debaryomyces hansenii and $1.2 \times 10^{7}$ cells $/ \mathrm{mL}$ Candida sp. (after 6 days fermentation in $20^{\circ} \mathrm{C}$ ). The density was similar to that of red seaweed fermented treatment with $10^{4}$ yeast cells $/ \mathrm{mL}$ in this study.

After fermentation, the protein contents increased in both SCD products from red (17.65 to $22.34 \%)$ and green seaweed (16.01 to $21.16 \%$ ). Felix and Pradeepa $(2011 ; 2012)$ found that crude protein in SCD product can reach up to $35 \%$, and it was higher than protein content in this study. The seaweed species and also the procedures to prepare SCD might affect the protein contents in harvested products. In addition, protein in yeast cells might play a role in increasing protein of SCD. The study of Ebrahim and Abou-seif (2008) showed that $S$. cerevisiae reached up to $42.03 \%$ crude protein. Percentage of crude protein varied among yeast products and ranged 
from $38.8 \%$ in Candida boidinii to $67.8 \%$ in Candida lipolytica (Shulz and Oslage, 1976). On the other hand, Uchida et al. (1997) suggested that the protein content of the SCD from Ulva fronds was approximately doubled by the attachment of bacteria, suggesting the enhanced Artemia growth is attributable to the combined effect of the SCD and the bacteria. In the present study, the total bacteria count in SCD solutions was not determined; however, it could be considered as supplementation food sources for Artemia.

Temperature was one of the most important factors that directly affected growth and reproduction of $\mathrm{Ar}$ temia; however, the temperature in this study was in the suitable range for $A$. franciscana. For A. franciscana Vinh Chau strain, they can grow well in temperature ranging from $22-35^{\circ} \mathrm{C}$. Nguyen Van Hoa et al. (2007) mentioned that if water temperature was low $\left(\leq 20^{\circ} \mathrm{C}\right)$, Artemia presented slow growth or mortality, and very high temperature $\left(>36^{\circ} \mathrm{C}\right)$ might cause heavy mortality, reduce reproduction and slow recover population. In this study, $\mathrm{pH}$ was also in suitable range for Artemia as Nguyen Van Hoa et al. (2007) reported that Artemia Vinh Chau strain could grow well in $\mathrm{pH}$ range 7-9.

The length of Artemia reached highest value at day 13 in treatment S50 $(7.45 \mathrm{~mm})$; however, these values were lower than those in the study of Ngo Thi Thu Thao and Nguyen Huynh Anh Huy (2017). These authors reported the length of Artemia at day $14(8.03 \pm 0.70 \mathrm{~mm})$ when feeding $50 \%$ shrimp feed and $50 \%$ SCD from red seaweed fermented with bacteria Lactobacillus. On the other hand, the study of Nguyen Thi Kim Phuong and Nguyen Van Hoa (2013) showed that length of Artemia cultured with $50 \%$ shrimp feed and 50\% Chaetoceros sp. at day 10 was $8.22 \pm 0.71 \mathrm{~mm}$. Overall, the increase in $\mathrm{Ar}$ temia's length in this study showed the pattern that at the first day, shrimp feed played an important role, and after that the replacement with SCD showed the effect of promoting the growth of this species. It is suggested that SCD diet could fulfill the requirement for growth performance of Artemia at the replacement proportions from 25 to $50 \%$, and the application should be from the on-growing or pre-adult stage since the nutritional compositions of $\mathrm{SCD}$ was not enough for the requirement of Artemia at first stage of life cycle.

The highest survival rates of $A$. franciscana in treatment S50 at day $14(93 \%)$ and day $21(71 \%)$ were higher than that $(61.1 \%)$ obtain at day 15 by Ngo Thi Thu Thao et al. (2015) when Artemia was fed with Chaetoceros sp. and supplementation with $B$. subtilis. Furthermore, the results in the present study was also higher than in the study of Ngo Thi Thu
Thao and Nguyen Huynh Anh Huy (2017) where the authors reported the survival rate of Artemia at $72 \%$ after 14-day culture with $50 \%$ SCD from $G$. tenuistipitata and 50\% shrimp feed. It is suggested that the mixture diet with SCD from red seaweed and shrimp feed at the ratio 50:50 could be able to maintain the high survival rate of Artemia and promise the utilization in biomass culture for this species. The lowest survival rates of Artemia presented in treatment CF (50\%), S100 (53\%) or S75 (58\%). The reasons for this issue might come from the accumulation of $\mathrm{NO}_{2}$ and $\mathrm{NH}_{4}{ }^{+}$and also the difference of nutritional contents in the diets. Dhont and Lavens (1996) reported that concentration of $1.000 \mathrm{mg} / \mathrm{L} \mathrm{NH}_{4}{ }^{+}$and $320 \mathrm{mg} / \mathrm{L} \mathrm{NO}_{2}$ did not affect growth and survival rate of Artemia larvae. Although the exchange of $30 \%$ water was conducted every 3 days, limited water volume and high concentration of $\mathrm{NO}_{2}$ and $\mathrm{NH}_{4}{ }^{+}$ might strongly affect survival rate in limited culture space and also in ongrowing stage of Artemia.

After 21 days of culture, the highest matching rate was in CF treatment (20.5\%) followed by S25 (18.5 $\%)$. These results were lower than the number of $37.58 \%$ in the study of Ngo Thi Thu Thao and Nguyen Thi Ngoan (2014) when authors fed Artemia with Chaetoceros algae; however, it was higher the number that Ngo Thi Thu Thao Thao and Nguyen Huynh Anh Huy (2017) reported at day 14 (10.3\%) when feeding Artemia with shrimp feed and SCD fermented with Lactobacillus at the ratio of 50:50. Probably, the experiment period was lasted longer in the present study compared to the previous study, and it could increase the matching rate of Artemia. Results of the length of female and male of Artemia at the matching and after several molting cycles showed that the diet with SCD replacement could obtained the results somewhat similar to the results of shrimp feed. Especially, the fecundity of Artemia at day 21 in SCD diets showed that with suitable replacement proportions SCD diet can be applied for growing Artemia. However, further studies need to be conducted to improve the nutritional values of SCD to find the suitable replacement in the diet and also which the life stage of cultured species should be applied for feeding.

\section{CONCLUSIONS AND RECOMMENDATIONS}

\subsection{Conclusions}

The supplementation of $10^{5}$ yeast cells $/ \mathrm{mL}$ in the fermentation of red seaweed (Gracillaria tenuistipitata) showed the best result in SCD yield and proximate compositions.

The diet with 50\% SCD from Gracillaria tenuistipitata and 50\% shrimp feed showed the best result in 
survival rate, growth rate and reproductive characteristics of Artemia franciscana after 21 days of culture.

\subsection{Recommendations}

Further study should be conducted to test the lower ratio of seaweed powder and water $(\mathrm{w} / \mathrm{v})$ for more effective SCD production.

\section{ACKNOWLEDGMENTS}

The author acknowledges Doan Huu Tin and other students in Mollusc Laboratory, College of Aquaculture and Fisheries, Can Tho University, Viet Nam for their help to collect data. We are grateful to staffs of Department of Coastal Aquaculture, College of Aquaculture and Fisheries, Can Tho University for their help and assistance during this study.

\section{REFERENCES}

Dhont, J. and Lavens, P., 1996. Tank production and use of ongrown Artemia. In: Lavens, P. and Sorgeloos, P., (Eds.). Manual on the production and use of live food for aquaculture (Editors). FAO Fisheries Technical Paper. No.361. Rome, FAO: pp. 164-195.

Ebrahim, M.S.M. and Abou-seif R.A., 2008. Fish meal replacement by yeast protein (Saccharomyces cerevisiae) supplemented with biogenic 1-carintine as a source of methionine plus lysine mixture in feed for Nile tilapia (Oreochromis niloticus) fingerlings. $8^{\text {th }}$ International Symposium on Tilapia in Aquaculture 2008.

Felix, S. and Pradeepa P., 2011. Single-cell detritus: fermented, bioenriched feed for marine larvae. Global Aquaculture Advocate, 21: 72-73.

Felix, S. and Pradeepa, P., 2012. Lactic acid fermentation of seaweed (Ulva reticulata) for preparing marine single cell detritus (MSCD). Tamilnadu J. Veterinary and Animal Sciences, 8(2): 76-81.

Nguyen Van Hoa, Nguyen Thi Hong Van, Nguyen Thi Ngoc Anh, Pham Thi Tuyet Ngan, Huynh Thanh Toi, and Tran Huu Le, 2007. Artemia - Research and use in Aquaculture. Agriculture Publishing House: 134 pages (in Vietnamese).

Camacho, A.P., Salinas, J.M., Fuertes, C. and Delgado, M., 2004. Preparation of single cell detritus from
Laminaria saccharina as a hatchery diet for bivalve mollusks. Marine Biotechnology 6 (6): 642-649.

Nguyen Thi Kim Phuong and Nguyen Van Hoa, 2013. The effects of food diets in the growth and some reproductive targets of Artemia franciscana (Vinh Chau strain). Can Tho University Journal of Science, Part B: Agriculture, Aquaculture and Biotechnology, 26: 34-42. (In Vietnamese with English abstract)

Tanyaros, S. and Chuseingjaw, S., 2016. A partial substitution of microalgae with single cell detritus pro.duced from seaweed (Porphyra haitanensis) for the nursery culture of tropical oyster (Crassostrea belcheri). Aquaculture Research, 47(7): 2080-2088.

Ngo Thi Thu Thao and Nguyen Thi Ngoan, 2014. The effects of additional biological products methods to the growth and reproduction of Artemia fransiscana Vinh Chau. Can Tho University Journal of Science, Part B: Agriculture, Aquaculture and Biotechnology, 32: 94-99. (in Vietnamese).

Ngo Thi Thu Thao, Pham Thi Tuyet Ngan and Nguyen Thi Bao Trang, 2015. Combined effects of salinnity and Bacillus subtilis supplementation on the growth and reproduction of Artemia franciscana. Can Tho University Journal of Science, Part B: Agriculture, Aquaculture and Biotechnology, 39: 118-127 (in Vietnamese).

Ngo Thi Thu Thao and Nguyen Huynh Anh Huy, 2017. Study on elaborating and utilizing SCD from red seaweed (Gracilaria tenuistipitata) for filter feeders. Can Tho University Journal of Science, Part B: Agriculture, Aquaculture and Biotechnology, 49: 91-99 (in Vietnamese).

Ngo Thi Thu Thao, Nguyen Van Hoa, Nguyen Huynh Anh Huy and Le Phuoc Trung, 2018. Evaluating preservation methods and quality of SCD harvested from gut weed, Enteromorpha intestinalis. Can Tho University Journal of Science, Special Issue for Aquaculture (1): 161-168 (in Vietnamese).

Uchida, M., 1996. Formation of single cell detritus densely covered with bacteria during experimental degradation of Laminaria japonica Thalli. Fisheries Sci., 62(5): 731-736.

Uchida, M., Nakata, K, and Maeda M., 1997. Conversion of Ulva fronds to a hatchery diet for Artemia nauplii utilizing the degrading and attaching abilities of Pseudoalteromonas espejiana. Journal of Applied Phycology, 9(6): 541-549. 